\title{
Erratum to: Efficacy of vaccination with La Sota strain vaccine to control Newcastle disease in village chickens in Nepal
}

\author{
Sulochana Shrestha $^{1} \cdot$ Mamta Dhawan $^{2} \cdot$ Meritxell Donadeu $^{3} \cdot$ Baptiste Dungu $^{4}$
}

Published online: 11 March 2017

(C) Springer Science+Business Media Dordrecht 2017

Erratum to: Trop Anim Health Prod (2017) 49:439-444

DOI 10.1007/s11250-016-1205-4

The Acknowledgement statement of the original article was published with a missing funder. The updated statement is shown below:

Acknowledgements We are grateful to the excellent assistance of Sharmila Dutta, Dr S.P Gautam, Ms K. Maharjan, Dr Sita Acharya, village animal health worker Krishna, Arjun, Radhika and the staff of CBPL for their help. We would like to thank Central Veterinary Laboratory, Tripureswor for providing the field virus. This article is based on research funded in part by the Bill \& Melinda Gates Foundation (Grant no. OPP1009497) and the UK Government. The findings and conclusions contained within are those of the authors and do not necessarily reflect positions or policies of the Bill \& Melinda Gates Foundation nor the UK Government.

The online version of the original article can be found at http://dx.doi.org/ $10.1007 / \mathrm{s} 11250-016-1205-4$.

Sulochana Shrestha

sulochana.shrestha@hester.com.np

1 Central Biological Production Laboratory, Tripureshwor, Kathmandu, Nepal

2 GALVmed, Unit 118 \& 120 B, Splendor Forum, Plot No 3, Jasola District Centre, Jasola, New Delhi 110025, India

3 Faculty of Veterinary and Agricultural Sciences, Veterinary Clinical Centre, The University of Melbourne, 250 Princes Highway,

Werribee, Victoria 3030, Australia

4 MCI Sante Animale, Lot 157, ZI Sud-Ouest, B.P. 278, 28810 Mohammedia, Morocco 